\title{
HUBUNGAN JENIS KELAMIN DAN UMUR DENGAN TINGKAT PENGETAHUAN REMAJA TENTANG HIV/AIDS DI SMAN 3 ATAMBUA NUSA TENGGARA TIMUR 2018
}

\author{
OLEH \\ PIUS A. L. BEREK ${ }^{1)}$ \\ MARIA FLORIDA BE ${ }^{2)}$ \\ YUSFINA MODESTA RUA ${ }^{3)}$ \\ CHRISTINA ANUGRAHINI ${ }^{4}$
}
1), 2), 3), 4) Program Studi Keperawatan Universitas Timor, Jln Wehor Kabuna Haliwen Atambua, Nusa Tenggara Timur, Post 85711. Phone: +6281280426042. Email francis_domin2012@yahoo.com.

\begin{abstract}
Masa remaja adalah masa dimana individu berada pada mobilitas sosial yang paling tinggi. Mobilitas sosial yang tinggi ini akan membuka peluang baginya untuk terpapar terhadap berbagai perubahan sosial, kultural, budaya, serta fisik maupun psikologis. AKibatnya remaja tersebut mempunyai kerentanan yang tinggi terhadap penularan berbagai jenis penyakit khususnya HIV/AIDS. Akhir-akhir ini terdapat kecenderungan peningkatan kasus HIV/AIDS khususnya pada kelompok remaja yang merupakan usia yang masih sangat produktif. Penelitian ini bertujuan untuk menganalisis hubungan antara jenis kelamin dan umur dengan tingkat pengetahuan remaja tentang HIV/AIDS di SMAN 3 Atambua. Metode analisis dilakukan berdasarkan jenis data yaitu karakteristik jenis kelamin dan umur sebagai variabel independen dan tingkat pengetahuan sebagai variable dependen. Selanjutnya uji analisis menggunakan dua tahap yaitu analisis univariat dan analisis bivariat. Hasil analisis bivariat menggunakan chi square diketahui tidak ada hubungan antara umur dengan tingkat pengetahuan remaja HIV/AIDS $(\mathrm{p}=0,591$ pada alfa 0,05$)$ namun terdapat hubungan yang bermakna antara jenis kelamin dengan tingkat pengetahuan remaja tentang HIV/AIDS dengan $\mathrm{p}=0,010$ pada alfa 0,05. Peningkatan penyuluhan pada remaja khususnya remaja laki-laki melalui peer grup yang melibatkan pihak sekolah menjadi hal penting untuk diprioritaskan mengingat usia remaja merupakan aset bangsa yang paling berharga.
\end{abstract}

Kata Kunci: HIV/AIDS, jenis kelamin, umur, tingkat pengetahuan 


\title{
Relationship Between Gender and Age With Adolescent Levels of Knowledge About HIV / AIDS at SMAN 3 Atambua, East Nusa Tenggara 2018
}

\author{
BY \\ PIUS A. L. BEREK ${ }^{1)}$ \\ MARIA FLORIDA BE ${ }^{2)}$ \\ YUSFINA MODESTA RUA ${ }^{3)}$ \\ CHRISTINA ANUGRAHINI ${ }^{4}$
}
1), 2), 3), 4) Nursing Program at University of Timor, Atambua Campus, Jl. Wehor Kabuna Haliwen Atambua, East Nusa Tenggara. Post 85711. Phone: +62812 8042 6042. Email: francis domin2012@yahoo.com

\begin{abstract}
Adolescence is a time when individuals are at the highest social mobility. This high social mobility will open up opportunities for him to be exposed to various social, cultural, cultural, as well as physical and psychological changes. As a result, these adolescents have a high susceptibility to the transmission of various types of diseases, especially HIV / AIDS. Lately there is a tendency to increase cases of HIV / AIDS, especially in teenagers who are still very productive age. This study aims to analyze the relationship between sex and age with the level of adolescent knowledge about HIV / AIDS in SMAN 3 Atambua. The method of analysis is based on the type of data that is gender characteristics and age as independent variable and level of knowledge as dependent variable. Furthermore, the analysis test using two stages of univariate analysis and bivariate analysis. The results of the bivariate analysis using chi square note there is no relationship between age and level of knowledge of adolescents with HIV / AIDS ( $p=0.591$ at 0.05 alpha) but there is a significant relationship between sex with adolescent knowledge level about HIV / AIDS with $p=0.010$ at alpha 0.05. Increasing counseling in adolescents, especially adolescent boys through peer groups involving the school becomes an important thing to be prioritized considering the age of adolescents is the most valuable asset of the nation.
\end{abstract}

Keywords : HIV / AIDS, gender, age, level of knowledge 
PENDAHULUAN

Pengetahuan merupakan hasil tahu dan ini terjadi setelah orang melakukan pengindraan terhadap suatu objek tertentu. Pengindraan terjadi melalui panca indera manusia, yakni indera penglihatan, pendengaran, penciuman, rasa dan raba (Notoatmodjo, 2003). AIDS (Acquired Immunodeficiency Syndrome) didefinisikan sebagai bentuk paling berat dalam rangkaian penyakit yang disebabkan oleh infeksi virus HIV (Human Immunodeficiency Virus). HIV disebabkan oleh sekelompok virus yang dikenal sebagai retrovirus. Virus ini membawa materi genetic dalam bentuk asam ribonukleat (RNA) dan bukan asam deoksiribonukleat (DNA) (Brunner \& Suddarth, 2013). Remaja merupa-kan kelompok yang paling rentan secara fisik dan psikis terhadap infeksi HIV, maka remaja menjadi fokus dari semua strategi penang-gulangan penyebaran virus HIV/ AIDS. Perubahan yang terjadi pada remaja mengakibatkan tingginya keinginan untuk mencoba terhadap berbagai hal baru yang belum mereka ketahui sebelumnya, (Veronika,dkk, 2012).
Data menyebutkan bahwa dari sekitar 40 juta penduduk dunia yang telah terinfeksi HIV, lebih dari 95\%nya berada di negara berkembang, dan anak-anak muda saat ini telah menjadi bagian dari pandemik AIDS dengan adanya data yang menyebutkan bahwa lebih dari setengah kasus baru yang terinfeksi HIV adalah remaja dengan usia antara 15-24. Hal ini diperkuat oleh perkiraan WHO, 50\% dari seluruh kasus terinfeksi adalah anak muda, atau dengan kata lain 7000 anak muda (umur 15-24 tahun) terinfeksi setiap harinya, dan 30\% dari 40 juta orang dengan HIV/AIDS (ODHA) yang terinfeksi seluruh dunia berada dalam kelompok usia 15-24 tahun. Mayoritas anak muda yang terinfeksi tidak tahu bahwa dia sebenarnya telah terinfeksi, dan anak muda yang terlibat hubungan seks, hanya sedikit yang tahu apakah pasangannya telah terinfeksi HIV atau tidak.

AIDS diperkirakan telah menginfeksi 38,6 juta orang diseluruh dunia. Selanjutnya, fenomena "gunung es" dalam kasus HIV/AIDS di Indonesia menjadi diskursus yang perlu mendapat 
perhatian. Pada tahun 2007, pendidikan diatas SMP sebesar perkembangan situasi epidemic HIV menunjukan peningkatan yang sangat tajam. Komisi Penanggulangan AIDS (KPA) mengungkapkan bahwa kasus HIV/AIDS tahun 2010 dari semua kelompok umur sejumlah 21.770 orang termasuk remaja. Meningkatnya jumlah remaja penderita HIV/AIDS dimungkinkan karena keterbatasan akses informasi dan layanan kesehatan yang berdampak pada rendahnya pengetahuan HIV/AIDS yang benar. Menurut KPA (2011) pemahaman remaja tentang HIV/AIDS masih sangat minim, padahal remaja termasuk kelompok usia yang rentan dengan perilaku beresiko. Pengetahuan HIV/AIDS di Indonesia masih rendah. Sudikno, dkk (2010) dalam penelitianya tentang pengetahuan HIV/AIDS pada remaja di Indonesia ditemukan bahwa prosentase pengetahuan HIV/AIDS dengan kategori baik pada remaja diperkotaan sebesar $54 \%$ dan dipedesaan sebesar 46,6\%. Dan disimpulkan lebih lanjut dalam penelitianya bahwa pengetahuan HIV/AIDS dengan kategori baik pada kelompok remaja dengan $58,6 \%$ lebih tinggi dibandingkan remaja dengan pendidikan dibawah SMP, yaitu 48,3\% (Sudikno, dkk 2010 ).

Cara untuk menghilangkan atau mengurangi perilaku beresiko merupakan tindakan yang sangat penting. Upaya pencegahan primer melalui program pendidikan yang efektif amat penting untuk pengendalian dan pencegahan. Sistem isolasi lainya yaitu Body Substance Isolation System (sistem pengisolasian substansi tubuh) yaitu: mencuci tangan, menggunakan sarung tangan, mengenakan gaun atau apron plastik, menggunakan masker, membuang jarum suntik dan benda tajam bekas pakai kedalam wadah yang kaku dan tahan tembus, tempatkan sampah dan kain kotor dalam kantong yang tertutup ketat, bersihkan barang-barang, peralatan atau perabotan yang kotor, kembangkan program untuk memastikan bahwa semua petugas kesehatan mematuhi system tindakan penjagaan infeksi (Brunner \& Suddarth, 2001).

Melihat fenomena diatas, peneliti tertarik untuk melakukan 
penelitian tentang "Hubungan antara karakteristik jenis kelamin dan umur dengan Tingkat Pengetahuan Remaja tentang HIV/AIDS di SMAN 3 Atambua, Nusa Tenggara Timur". Penelitian ini dilakukan untuk melihat adanya hubungan antara jenis kelamin dan umur dengan tingkat pengetahuan remaja tentang HIV/AIDS di SMAN 3 Atambua.

\section{METODOLOGI}

Desain penelitian dalam penelitian ini adalah penelitian analitik korelasi dengan pendekatan cros sectional yang bertujuan untuk menganalisis hubungan antara jenis kelamin dan umur dengan tingkat pengetahuan remaja tentang HIV/AIDS di SMAN 3 Atambua, Nusa Tenggara Timur. Jumlah sampel dalam penelitian ini adalah 96 orang responden yang dipilih dengan menggunakan eknik non probability sampling dengan menggunakan teknik purposive sampling yaitu dengan cara memilih sampel diantara populasi sesuai dengan yang dikehendaki peneliti. Kriteria inklusi adalah siswa-siswi kelas XI yang bersedia menjadi responden.
Berkaitan dengan etik penelitian, peneliti telah menjelaskan tujuan dan manfaat penelitian kepada responden dan siswa-siswi yang bersedia menjadi responden menandatangani lembar persetujuan menjadi responden. Selain itu peneliti juga menyadari bahwa penelitian ini tidak menimbulkan resiko cedera pada responden. Persetujuan ijin penelitian juga telah diberikan oleh pihak Prodi Keperawatan Unimor, Kesatuan Bangsa dan Politik Kabupaten Belu, serta Kepala Sekolah SMAN 3 Atambua. Peneliti melakukan pengambilan data dengan cara menyebarkan kuisioner kepada responden. Kuisioner meliputi data demografi jenis kelamin dan umur serta tingkat pengetahuan tentang HIV/AIDS.

Analisa data yang digunakan dalam penelitian ini adalah dengan menggunakan analisa univariat dan bivariat. Analisa univariat, yaitu mengidentifikasi jenis kelamin dan umur responden serta tingkat pengetahuan remaja tentang HIV/AIDS. Sedangkan analisis bivariat dilakukan dengan tujuan 
untuk mengetahui ada tidaknya hubungan antara jenis kelamin dan umur dengan tingkat pengetahuan remaja tentang HIV/AIDS. Uji hipotesis yang digunakan adalah uji chi square dengan kemaknaan nilai $\alpha$ atau p-value $<0,05$. Hasil penelitian ditampilkan dalam bentuk tabel dan diinterpretasikan secara deskriptif.

\section{HASIL}

Tabel 1 menunjukkan bahwa hampir sebagian besar responden dalam penelitian ini adalah berjenis kelamin perempuan yaitu sebesa $60,4 \%$ sisanya adalah berjenis kelamin laki-laki yaitu sebesar $39,6 \%$.

Tabel 1 Distribusi Frekuensi Responden Berdasarkan Jenis Kelamin Di SMAN 3 Atambua, Mei $2018(n=96)$

\begin{tabular}{ccc}
\hline $\begin{array}{c}\text { Jenis } \\
\text { Kelamin }\end{array}$ & Frekuensi & Persentase (\%) \\
\hline Laki-Laki & 38 & 39,6 \\
Perempua & 58 & 60,4 \\
$\mathrm{n}$ & & \\
\hline Total & $\mathbf{9 6}$ & $\mathbf{1 0 0}$ \\
\hline
\end{tabular}

Tabel 2 diketahui bahwa rata-rata umur responden dalam penelitian ini adalah 17.14 tahun (95\% CI: 16.93 17.34), dengan standar deviasi 1.022 tahun. Umur termuda 15 tahun dan tertua adalah 20 tahun. Dari estimasi interval dapat disimpulkan bahwa 95\% diyakini bahwa rata-rata umur responden dalam penelitian ini adalah diantara 16,93 sampai dengan 17,34 tahun.

Tabel 2 Distribusi Frekuensi

Responden Berdasarkan Umur

Di SMAN 3 Atambua, Mei 2018

$(\mathbf{n}=96)$

\begin{tabular}{ccccc}
\hline Var & Mean & SD & Min-Mak & 95\% CI \\
\hline Umur & \multirow{2}{*}{17.14} & 1.022 & $15-20$ & $\begin{array}{c}16.93- \\
\end{array}$ \\
& & & & 17.34 \\
\hline
\end{tabular}


yang memiliki pengetahuan pada kategori cukup dan kurang berturutturut adalah $19,8 \%$ dan $20,8 \%$.

Tabel. 4 Distribusi Frekuensi Tingkat Pengetahuan Remaja Tentang HIV/AIDS Pada Ranah Memahami (Comprehension), Mei 2018

\begin{tabular}{cccc}
\hline Variabel & Kategori & Frekuensi & $(\boldsymbol{\%})$ \\
\hline \multirow{3}{*}{ Memahami } & Baik & 47 & 49,0 \\
\cline { 2 - 4 } & Cukup & 40 & 41,7 \\
\cline { 2 - 4 } & Kurang & 9 & 9,3 \\
\hline & Total & 96 & 100 \\
\hline
\end{tabular}

Berdasarkan pada tabel 4 diatas dapat diketahui bahwa tingkat pengetahuan remaja tentang HIV/AIDS pada ranah memahami (C2) adalah berturut-turut sebagai berikut $49 \%$ responden memiliki pengetahuan baik, $41,7 \%$ memiliki pengetahuan cukup, dan masih terdapat $9,3 \%$ responden yang memiliki pengetahuan kurang.

Tabel. 5 Distribusi Frekuensi Tingkat Pengetahuan Remaja Tentang HIV/AIDS Pada Ranah Tahu (C1) dan Memahami (C2), Mei 2018 (n=96)

\begin{tabular}{cccc}
\hline Variabel & Kategori & Frekuensi & $\mathbf{( \% )}$ \\
\hline Tingkat & Baik & 36 & 37,5 \\
\cline { 2 - 4 } pengetahuan & Cukup & 56 & 58,3 \\
\cline { 2 - 4 }$(\mathrm{C} 1, \mathrm{C} 2)$ & Kurang & 4 & 4,2 \\
\hline & Total & 96 & 100 \\
\hline
\end{tabular}

Berdasarkan pada tabel 5 diatas dapat diketahui bahwa tingkat pengetahuan remaja tentang HIV/AIDS pada ranah $\mathrm{C} 1$ dan $\mathrm{C} 2$ adalah sebagai berikut: terdapat 56 orang $(37,5 \%)$ remaja SMAN 3 Atambua memiliki pengetahuan yang cukup tentang HIV/AIDS. Dan terdapat 36 orang $(37,5 \%)$ responden yang memiliki pengetahuan yang baik tentang HIV/AIDS; namun masih terdapat 4 orang $(4,2 \%)$ responden yang memiliki pengetahuan kurang tentang HIV/AIDS.

Tabel 6 Hubungan Antara Jenis Kelamin dengan Tingkat Pengetahuan Remaja Tentang HIV/AIDS di SMAN 3 Atambua, Mei $2018(n=96)$

\begin{tabular}{|c|c|c|c|c|c|c|c|c|c|}
\hline \multirow{3}{*}{$\begin{array}{c}\text { Jenis } \\
\text { Kelamin }\end{array}$} & \multicolumn{6}{|c|}{ Tingkat Pengetahuan } & \multirow{3}{*}{$\begin{array}{c}\begin{array}{c}\text { Tot } \\
\text { al }\end{array} \\
\mathbf{N}\end{array}$} & \multirow{3}{*}{$\%$} & \multirow{3}{*}{$\begin{array}{c}\mathbf{P} \\
\text { value }\end{array}$} \\
\hline & \multicolumn{2}{|c|}{ Kurang } & \multicolumn{2}{|c|}{ Cukup } & \multicolumn{2}{|c|}{ Baik } & & & \\
\hline & $n$ & $\%$ & $\bar{n}$ & $\%$ & $\mathrm{n}$ & $\%$ & & & \\
\hline Laki-laki & 0 & 0 & 29 & 76.3 & 9 & 23.7 & 38 & 100 & 0,010 \\
\hline $\begin{array}{l}\text { Perempua } \\
\mathrm{n}\end{array}$ & 4 & 6,9 & 27 & 46,6 & 27 & 46,6 & 58 & 100 & \\
\hline Jumlah & 4 & 4,2 & 56 & 58,3 & 36 & 37,5 & 96 & 100 & \\
\hline
\end{tabular}

Hasil analisis hubungan antara jenis kelamin dengan tingkat pengetahuan remaja tentang HIV/AIDS diperoleh bahwa ada sebanyak 9 orang $(23,7 \%)$ remaja laki-laki memiliki pengetahuan yang baik tentang HIV/AIDS, dan terdapat 27 orang $(46,6 \%)$ remaja perempuan yang memiliki pengetahuan yang baik 
tentang HIV/AIDS. Hasil uji statistik diperoleh nilai $\mathrm{p}=0,010$ maka disimpulkan bahwa ada hubungan yang signifikan antara jenis kelamin dengan tingkat pengetahuan remaja di SMAN 3 Atambua.

Tabel 7 Hubungan Antara Umur Dengan Tingkat Pengetahuan Remaja Tentang HIV/AIDS di SMAN 3 Atambua, Mei 2018

\begin{tabular}{|c|c|c|c|c|c|c|c|c|c|}
\hline \multirow[t]{3}{*}{ Umur } & \multicolumn{6}{|c|}{ Tingkat Pengetahuan } & \multicolumn{2}{|c|}{ Total } & \multirow{2}{*}{$\begin{array}{c}P \\
\text { value }\end{array}$} \\
\hline & \multicolumn{2}{|c|}{ Kurang } & \multicolumn{2}{|c|}{ Cukup } & \multicolumn{2}{|c|}{ Baik } & & & \\
\hline & $\mathbf{n}$ & $\%$ & $\mathbf{n}$ & $\%$ & $\mathbf{n}$ & $\%$ & $\mathbf{n}$ & $\%$ & \\
\hline $15 \mathrm{Thn}$ & 0 & 0 & 1 & 25 & 3 & 75 & 4 & 100 & 0,591 \\
\hline $16 \mathrm{Thn}$ & 0 & 0 & 14 & 58,3 & 10 & 41,7 & 24 & 100 & \\
\hline 17 Thn & 1 & 3,3 & 18 & 60 & 11 & 36,7 & 30 & 100 & \\
\hline $18 \mathrm{Thn}$ & 2 & 6,3 & 20 & 62,5 & 10 & 31,3 & 32 & 100 & \\
\hline 19 Thn & 1 & 20 & 2 & 40 & 2 & 40 & 5 & 100 & \\
\hline $20 \mathrm{Thn}$ & 0 & 0 & 1 & 100 & 0 & 0 & 1 & 100 & \\
\hline Jumlah & 4 & 4,2 & 56 & 58,3 & 36 & 37,5 & 96 & 100 & \\
\hline
\end{tabular}

Hasil analisis hubungan antara umur dengan tingkat pengetahuan remaja tentang HIV/AIDS diketahui bahwa pengetahuan yang baik tentang HIV/AIDS di SMAN 3 Atambua berdasarkan kelompok umur berada pada kelompok umur 15 tahun yaitu sebanyak 3 orang dari 4 remaja (75\%). Sedangkan remaja yang berpengetahuan baik pada kelompok umur 16 tahun, 17 tahun, 18 tahun, 19 tahun dan 20 tahun adalah berturut-turut adalah sebagai berikut:
$41,7 \% ; 36,7 \% ; 31,3 \%$ dan $40 \%$ serta 0\% untuk kelompok umur 20 tahun. Hasil uji statistik diperoleh nilai $\mathrm{p}=$ 0,591 maka disimpulkan bahwa tidak ada hubungan antara umur dengan tingkat pengetahuan remaja tentang HIV/AIDS di SMAN 3 Atambua.

\section{PEMBAHASAN}

Responden dalam penelitian ini, jenis kelamin laki- laki 38 orang $(39,6 \%)$ dan perempuan sebanyak 58 orang $(60,4 \%)$. Jenis kelamin merupakan unsur biologis manusia hasil ciptaan sang Khalik. Pertemuan antara pria dan wanita dalam konteks hubungan seks akan menghasilkan keturunan untuk melangsungkan kehidupan manusia. Namun sebaliknya jika persoalan hubungan sex dimaksud disalahgunakan maka akan mendatangkan malapetaka. Hasil penelitian ini ditemukan bahwa $60,4 \%$ responden berjenis kelamin perempuan, dan $39,6 \%$ berjenis kelamin laki-laki. Hasil analisis lebih lanjut menggunakan analisis chi square diketahui bahwa remaja yang memiliki pengetahuan yang baik berdasarkan jenis kelamin adalah sebagai berikut, laki-laki sebanyak $23,7 \%$ dan perempuan sebanyak 
46,6\%. Disimpulkan bahwa remaja perempuan cenderung memiliki tingkat pengetahuan yang baik tentang HIV/AIDS jika dibandingkan dengan laki-laki. Hal ini kemungkinan disebabkan karena remaja wanita memiliki lebih banyak waktu untuk membaca atau berdiskusi dengan teman sebaya terkait penyakit HIV/AIDS.

Rendahnya tingkat pengetahuan remaja laki-laki ten-tang bahaya dan penularan HIV / AIDS akan mendukung mening-katkan angka kejadian HIV/AIDS karena terbuka peluang bagi kaum remaja laki-laki untuk terlibat dalam hubungan sex. Hal ini sejalan dengan penelitian yang dilakukan oleh Klau, Sukmawati, Berek dkk (2018) yang mengatakan bahwa keterlibatan yang sering dilakukan laki-laki dalam hubungan seksual dengan pekerja seks perempuan (WPS) tanpa menggunakan kondom menempatkan mereka pada risiko tinggi untuk infeksi HIV. Data menyebutkan bahwa dari sekitar 40 juta penduduk dunia yang telah terinfeksi HIV, lebih dari 95\%-nya berada di negara berkembang, dan anak-anak muda saat ini telah menjadi bagian dari pandemik
AIDS dengan adanya data yang menyebutkan bahwa lebih dari setengah kasus baru yang terinfeksi HIV adalah remaja dengan usia antara 15-24.1 Hal ini diperkuat oleh perkiraan WHO, 50\% dari seluruh kasus terinfeksi adalah anak muda, atau dengan kata lain 7000 anak muda (umur 15-24 tahun) terinfeksi setiap harinya, dan 30\% dari 40 juta orang dengan HIV/AIDS (ODHA) yang terinfeksi seluruh dunia berada dalam kelompok usia 15-24 tahun. Mayoritas anak muda yang terinfeksi tidak tahu bahwa dia sebenarnya telah terinfeksi, dan anak muda yang terlibat hubungan seks, hanya sedikit yang tahu apakah pasangannya telah terinfeksi HIV atau tidak. (Sosodoro, Emilia, Wahyuni, 2009).

Peneliti berasumsi bahwa remaja laki-laki cenderung tidak mengembangkan pengetahuannya tentang HIV/AIDS dibandingkan dengan remaja perempuan. Hal ini akan berdampak pada perilaku hidup yang beresiko tertularkan HIV / AIDS. Semakin seseorang remaja tidak mengetahui tentang sesuatu hal terutama HIV/AIDS, maka ia akan 
hidup dalam ketidaktahuannya, dan jika dihadapkan pada masa-masa puber yang tidak terkendali, tidak menutup kemungkinan remaja tersebut bisa terjerumus dalam pergaulan bebas dan terlibat dalam praktik seks bebas ataupun perilakuperilaku lainnya yang beresiko tertular HIV/AIDS seperti tatto, tindik telinga, minum minuman keras, dan lain-lain.

Hasil analisis menunjukkan bahwa rata-rata pengetahuan remaja tentang HIV/AIDS pada tingkat baik adalah hanya 37,---\%. Dari kelompok umur yang paling tinggi adalah umur 15 tahun dimana $75 \%$ nya memiliki pengetahuan yang baik. Sedang kelompok umur lainnya dibawah $41 \%$. Hasil analisis lebih lanjut pada alfa 0,05 diketahui bahwa tidak ada hubungan antara umur dengan tingkat pengetahuan remaja tentang HIV/AIDS di SMAN 3 Atambua.

Penelitian ini tidak sejalan dengan penelitian dari Pratiwi \& Basuki (2011) yang mengatakan bahwa terdapat hubungan yang signifikan antara umur dengan pengetahuan tentang penularan
HIV/AIDS di Denpasar Bali. Dijelaskan lebih lanjut bahwa masa remaja merupakan masa peralihan baik secara fisik, psikis maupun sosial dari masa kanak-kanak menuju dewasa. Pada masa ini adalah perpaduan antara perkembangan usia psikologis dan usia biologis sehingga sangat dipengaruhi multifaktor yang terjadi di berbagai bidang dalam masyarakat bertambahnya kasus penyakit menular seksual terutama HIV-AIDS, kematian ibu muda yang masih sangat tinggi, merebaknya praktek aborsi karena kehamilan yang tidak diinginkan dan kecenderungan remaja masa kini untuk melakukan hubungan seksual sebelum nikah. Masalah ini tidak dapat didekati hanya dari aspek klinis oleh para ahli kedokteran. Inti persoalan sesungguhnya terletak pada konteks sosial yang sangat kompleks karena kesehatan repro-duksi politik, sosial dan ekonomi dan berhubungan erat dengan nilai, etika, agama dan kebudayaan.

Masa remaja merupakan masa pencarian jati diri yang mendorongnya mempunyai rasa keingintahuan yang tinggi, ingin tampil menonjol, dan diakui eksistensinya. Namun 
disisi lain remaja mengalami ketidakstabilan emosi sehingga mudah dipengaruhi teman dan mengutamakan solidaritas kelompok. Pada usia remaja, akibat pengaruh hormonal, juga mengalami perubahan fisik yang cepat dan mendadak. Perubahan ini ditunjuk-kan dari perkembangan organ seksual menuju kesempurnaan fungsi serta tumbuhnya organ seksual sekunder. Hal ini menjadikan remaja sangat dekat dengan permasalahan seputar seksual. Namun terbatasnya bekal informasi yang dimiliki menjadikan remaja memang masih memerlukan perhatian dan pengarah-an. Ketidakpekaan orang tua dan pendidik terhadap kondisi remaja menyebabkan mereka sering terjatuh pada kegiatan tuna sosial. Ditambah lagi keengganan dan kecanggungan remaja untuk bertanya pada orang yang tepat semakin menguatkan alasan kenapa remaja sering bersikap tidak tepat terhadap organ reproduksinya. Data menunjukkan dari remaja usia 12-18 tahun, 16\% mendapat informasi seputar seks dari teman, $35 \%$ dari fi $1 m$ porno, dan hanya $5 \%$ dari orang tua. Remaja dalam perkem-bangannya memerlu- kan lingkungan adaptif yang menciptakan kondisi yang nyaman untuk bertanya dan membentuk karakter bertanggung jawab terhadap dirinya. Ada kesan pada remaja, seks itu menyenangkan, puncak rasa kecintaan, yang serba membahagia-kan sehingga tidak perlu ditakutkan. Berkembang pula opini seks adalah sesuatu yang menarik dan perlu dicoba (sexpectation). Terlebih lagi ketika remaja tumbuh dalam lingkungan mal-adaptif, akan mendorong terciptanya perilaku amoral yang merusak masa depan remaja. Dampak pergaulan bebas mengantarkan pada kegiatan menyimpang seperti seks bebas, tindak kriminal termasuk aborsi, narkoba, serta berkembangnya penyakit menular seksual (PMS).

\section{KESIMPULAN}

Hasil penelitian menunjukkan bahwa tingkat pengetahuan remaja tentang HIV/ AIDS di SMAN 3 Atambua dalam hal tahu (know) adalah $59,4 \%$ pada kategori baik; tingkat pengetahuan remaja tentang HIV/ AIDS di SMAN 3 Atambua dalam hal memahami (Comprehen- 
sion) adalah 48,9\% kategori cukup; tingkat pengetahuan remaja tentang HIV/ AIDS di SMAN 3 Atambua dalam hal tahu dan memahami adalah $58,33 \%$ pada kategori cukup; terdapat hubungan yang bermakna antara jenis kelamin dengan tingkat pengetahuan remaja tentang HIV / AIDS di SMAN 3 Atambua $(\alpha=$ 0,010); dan tidak terdapat hubungan antara umur dengan tingkat pengetahuan remaja tentang HIV / AIDS di SMAN 3 Atambua.

Disarankan untuk peneliti selanjutnya agar melakukan penelitian tentang kurangnya pengetahuan remaja tentang HIV/AIDS, dengan mengembangkan lagi berbagai variabel dan kuisioner yang lebih baik agar hasil peneliti bisa digeneralisasikan pada semua remaja secara global.

\section{DAFTAR PUSTAKA}

Arikunto, Suharsini. 2006. Prosedur Penelitian Suatu Pendekatan Praktik. Jakarta: Rineka Cipta Bararah \& Jauhad. 2013. Asuhan Keperawatan Panduan Lengkap Menjadi Perawat
Profesional Jilid II. Jakarta : Pustakaraya

Brunner \& Suddarth. 2001. Buku Ajar Keperawatan Medikal Bedah Edisi 8. Jakarta: EGC Brunner \& Suddarth. 2013. Buku Ajar Keperawatan Medikal Bedah Edisi 12. Jakarta: EGC Budiman, dkk. 2014. Kapita Selekta Kuisioner Pengetahuan dan Sikap Dalam Penelitian Kesehatan. Jakarta : Salemba Medika

Fauk, N.K., Sukmawati, A.S., Berek, P.A.L, et all. (2018). Barriers to HIV Testing Among Male Clients of Female Sex Workers in Indonesia. International Journal For Equity In Health. Vol. 17; 2018

Fernandes Gregorius, et al. 2008. HIVI AIDS, PMS Dan Masyarakat Kita

Nurarif Huda Amin. 2015. Aplikasi Asuhan Keperawatan Berdasarkan Diagnosa Medis NANDA NIC-NOC. Jogjakarta : Mediaction

Nursalam. 2013. Asuhan Keperawatan Pada Pasien 
Terinfeksi HIV/AIDS Edisi 8.

Jakarta : Salemba Medika

Pratiwi, N. L., \& Basuki, H. (2011).

Hubungan Karakteristik

Remaja Terkait Resiko

Penularan HIV/AIDS dan

Perilaku Seks Tidak Aman di

Indonesia. Buletin Penelitian

Sistem Kesehatan Vol. 14

Nomor 4 Oktober 2011: 346

-357 .

Sosodoro, O., Emilia, O., \&

Wahyunu, B. (2009).

Hubungan Pengetahuan

Tentang HIV/AIDS Dengan

Stigma Orang Dengan

HIV/AIDS Di Kalangan

Pelajar SMA. Jurnal Berita

Kedokteran Masyarakat Vol.

25, No 4, Desember 2009.

Hal $210-217$

Sudikno, et al. 2010. Jurnal Pengetahuan HIV/AIDS Pada

Remaja Di Indonesia

Suparyanto. 2015. Resep Kebidanan

Metodologi dan Aplikasi.

Jogjakarta

Veronika Rina, dkk. 2012. Jurnal

Gambaran Pengetahuan

Remaja Tentang HIV/ AIDS
Widoyono. 2008. Penyakit Tropis, Epidemiologi, Penularan, Pencegahan, dan Pemberantasannya. Jakarta : Erlangga 